DOI: $10.19195 / 0524-4544.327 .25$

\author{
ALEKSANDRA SZADOK-BRATUŃ \\ ORCID: 0000-0001-8897-216X \\ aleksandra.szadok-bratun@uwr.edu.pl \\ Uniwersytet Wrocławski \\ MAREK BRATUŃ \\ ORCID: 0000-0002-7720-4461 \\ marek.bratun@uwr.edu.pl \\ Uniwersytet Wrocławski
}

\title{
O niektórych kategoriach filozoficznych w twórczości administracyjnoprawnej profesora Jana Bocia
}

\begin{abstract}
Abstrakt: Autorzy artykułu analizują wybrane kategorie filozoficzne w twórczości administracyjnoprawnej profesora Jana Bocia. Chcą zwrócić uwagę czytelnika na obecność refleksji filozoficznej w pracach przedstawiciela wrocławskiej szkoły kameralistyki. Podstawą rozważań są następujące teksty profesora: monografie Obywatel wobec ingerencji współczesnej administracji, Gmina w Belgii, hasła autorskie zawarte w Prawniczym słowniku wyrazów trudnych oraz artykuł Normatywizacja wartości w prawie administracyjnym (współautor: P. Lisowski). Artykuł rozpoczyna się od przypomnienia podstawowych faktów z życiorysu profesora Jana Bocia. Następnie poddane badaniu zostało pojęcie „obywatela”, analizowane w kontekście historiozoficznym i administracyjnoprawnym. Kolejne kategorie filozoficzne, rozpatrywane w aspekcie porównawczym, to: „autonomia”, „heteronomia”, „naturalizm etyczny”, „relatywizm etyczny”, „,wartość” i „aksjologia”. W podsumowaniu swoich analiz autorzy podkreślają obiektywną pochwałę aksjonormatywności profesora Jana Bocia, która pojawia się w jego badaniach, a także bardzo wysoki poziom ich merytoryczności, oryginalności i ciągłej, pogłębionej refleksji filozoficznej. W szczególny sposób podkreślają, że związek myślenia filozoficznego z myśleniem administracyjnym był cenną wartością kultury prawniczej Jana Bocia.
\end{abstract}

Słowa kluczowe: prawo administracyjne, aksjologia, wartość, autonomia, heteronomia, etyczny relatywizm, etyczny naturalizm, obywatel, Jan Boć. 


\section{O czym piszemy}

Prezentowany artykuł dotyczy wybranych kategorii filozoficznych występujących w twórczości administracyjnoprawnej Jana Bocia. Za sprawą tego szkicu pragniemy zwrócić uwagę na obecność refleksji filozoficznej w pracach reprezentanta wrocławskiej szkoły kameralistyki. Konstrukcja rozważań, dedykowanych pamięci Profesora, zbudowana jest na pewnej odwrotności wobec jego dorobku $\mathrm{z}$ toposem administracyjnoprawnym zajmującym centralne miejsce. My zderzamy to miejsce z toposem filozoficznym, starając się potwierdzić tezę o prymarności kategorii sapiencjalnych (uniwersalnych) wobec prawniczo-administracyjnych (partykularnych). Pomimo apriorycznej rozdzielności obu typów wiedzy zamierzamy zwrócić uwagę na pojęcia dwuwartościowe normatywnie, mające uzasadnienie tetyczno-moralne. Pojęcia stanowiące swoiste narzędzia w zakreślaniu pól wspólnych dla aksjologii prawa administracyjnego. Za podstawę naszych rozmyślań bierzemy zróżnicowane gatunkowo teksty powstałe w różnych okresach twórczości Jana Bocia na przestrzeni trzydziestu lat, zwłaszcza monografie: Obywatel wobec ingerencji wspótczesnej administracji, Gmina w Belgii ${ }^{1}$, hasła autorskie zawarte w Prawniczym slowniku wyrazów trudnych ${ }^{2}$ oraz artykuł Normatywizacja wartości w prawie administracyjnym (z Piotrem Lisowskim) zawarty w pracy zbiorowej Wartości w prawie administracyjnym ${ }^{3}$.

\section{Co (po)wiemy o Profesorze}

Jan Boć (1939-2017), profesor zwyczajny Uniwersytetu Wrocławskiego był jednym z wybitniejszych polskich prawników administratywistów ${ }^{4}$. Miał w swoim dorobku naukowym ponad 300 publikacji z obszaru administracji, prawa administracyjnego, ochrony środowiska, prawa konstytucyjnego i komparatystyki prawniczej, w tym 271 prac autorskich i współautorskich oraz 31 prac redagowanych samodzielnie i przy udziale współredaktorów. Wedle określenia Francisz-

1 J. Boć, Obywatel wobec ingerencji współczesnej administracji, Wrocław 1985; idem, Gmina w Belgii, Wrocław 1993.

2 Prawniczy słownik wyrazów trudnych, red. J. Boć, Wrocław 2005.

3 J. Boć, P. Lisowski, Normatywizacja wartości w prawie administracyjnym, [w:] Wartości w prawie administracyjnym, red. J. Zimmermann, Warszawa 2015, s. 19-43.

${ }^{4}$ Podstawowe fakty z biografii Prof. Jana Bocia podajemy za A. Szadok-Bratuń, W nauce nie ma pożegnań - pamięci Profesora Jana Bocia, „Studia Prawa Publicznego” 2017, nr 1, s. 157-166. Por. J. Jeżewski, Jan Boć (1939-2017), „Państwo i Prawo” 2017, z. 4, s. 118-121; Między tradycja a przyszłościa w nauce prawa administracyjnego. Księga jubileuszowa dedykowana Profesorowi Janowi Bociowi, red. J. Supernat, Wrocław 2009; Profesora Jana Bocia styl - stowa - szkoła, red. A. Szadok-Bratuń, Wrocław 2009. 
ka Longchampsa de Bériera (1912-1969) profesora Jana Bocia wypada uznać za współtwórcę wrocławskiej szkoły kameralistyki, zainicjowanej jeszcze na Uniwersytecie Jana Kazimierza we Lwowie, a twórczo kontynuowanej na Uniwersytecie Wrocławskim. Do końca życia pozostał wierny jej programowi wyrażającemu się w trzech założeniach, a były nimi: arystotelesowskie poszukiwanie prawdy dla niej samej, iście kantowski obiektywizm oraz wolne od postawy dogmatycznej nauczanie akademickie. Prowadził badania komparatystyczne, w czym niewątpliwie pomogły liczne stypendia naukowe i zagraniczne pobyty badawcze (Francja, Szwajcaria, Belgia, Niemcy, Meksyk). Wraz z Profesorem Konradem Nowackim (1946-2017) współkształtował powołaną do życia serię wydawniczą „Prawo Publiczne Porównawcze”, będącą w zamyśle próbą przybliżenia polskiemu odbiorcy oryginalnych prac uczonych krajowych i zagranicznych dotyczących problematyki administracyjnoprawnej innych państw. Był współpracownikiem Polsko-Niemieckiego Centrum Badawczego Prawa Publicznego i Ochrony Środowiska, międzyuczelnianej jednostki badawczej Uniwersytetu Wrocławskiego i Brandenburskiego Uniwersytetu Technicznego w Cottbus-Senftenberg. W ciągu długoletniej pracy dydaktycznej wykształcił całe zastępy licencjatów i magistrów; był promotorem siedemnastu doktoratów i recenzentem trzydziestu prac habilitacyjnych i doktorskich. Uhonorowany został rozlicznymi nagrodami i odznaczeniami (zarówno uniwersyteckimi, jak i państwowymi). Był wielkim miłośnikiem przyrody ojczystej i jako pierwszy wprowadził do programu nauczania wrocławskiej Alma Mater przedmiot prawo ochrony środowiska.

\section{Filozofujący administratywista w dialogicznej przestrzeni nauk}

\section{1.}

Rozpocznijmy od analizy pojęcia „obywatel”, stanowiącego centralną kategorię rozważań w monografii Jana Bocia Obywatel wobec ingerencji współczesnej administracji. Przypomnijmy zatem podstawowe kwestie związane z rzeczonym terminem. W ujęciu historiozoficznym idea obywatelstwa zakorzeniona jest w myśli filozoficznoprawnej antycznej Grecji i Rzymu ${ }^{5}$. Jak podaje Krzysztof Wroczyński, obywatel (gr. polites, od polis — miasto, społeczność, państwo; łac. civis) to politycznie i cywilnie wolny człowiek społeczności państwowej określającej jego

${ }^{5}$ Idea obywatelstwa jest tworem cywilizacji europejskiej. W innych kręgach kulturowych (np. azjatyckim czy indyjskim) taki fenomen nie mógł zaistnieć, gdyż poza światem zachodnim nie wykształciła się koncepcja polis / civitas w sensie jednolitej społeczności, tak jak i nie wykształciła się koncepcja praw człowieka. 
prawa i obowiązki ${ }^{6}$. W starożytności greckiej statusem obywatela cieszyli się wyłącznie wolni mężczyźni posiadający majątek. Tylko oni mieli m.in. czynne i bierne prawo wyborcze, pełnię praw politycznych czy prawo do sądu ${ }^{7}$. Nie przysługiwał natomiast status obywatela kobietom, dzieciom, niewolnikom, cudzoziemcom oraz członkom męskiej społeczności pozbawionym własności. W wielonarodowym państwie rzymskim od edyktu Karakalli obywatelstwo przysługiwało prawie wszystkim wolnym mężczyznom całego imperium, a nie jak pierwotnie jedynie mieszkańcom Rzymu. Status ten oznaczał posiadanie ius civitatis w obszarach: prawa publicznego (np. prawo głosowania, piastowania godności państwowych) i prawa prywatnego (np. prawo zawierania małżeństw czy umów) ${ }^{8}$. Wzorzec dobrego obywatela, tak grecki (agathos polites), jak i rzymski (vir honestus et bonus civis $^{9}{ }^{9}$, był ściśle powiązany z respektowaniem kardynalnych wartości etycznych w społeczeństwie zjednoczonym prawem w celu realizowania dobra wspólnego rzeczpospolitej ${ }^{10}$. W średniowieczu etyczno-prawne pojęcie obywatelstwa traktowane jako przedmiot badawczy ustąpiło miejsca problematyce obywatelstwa stanowego. Bycie obywatelem oznaczało zróżnicowanie praw i obowiązków stosownie do pozycji społecznej, urodzenia i majątku (feudałowie, rycerze, mieszczanie). Odrębne prerogatywy zdobywały także gminy i zrzeszenia (uniwersytety, cechy, gildie), rozwijało się obywatelstwo miejskie i korporacyjne.

Współczesny termin „obywatel” ukształtował się pod wpływem oświeceniowych idei Johna Locke'a, Charles'a de Montesquieugo czy Jeana Jacques'a Rousseau przełożonych na język przemian społecznych rewolucji francuskiej. Praktyczna filozofia wolnomyślicieli przyniosła pierwszą jurydyczną konstrukcję obywatelstwa, odchodzącą od obowiązków poddanych na rzecz uprawnień obywatelskich (Deklaracja Praw Człowieka i Obywatela z 1789) ${ }^{11}$. W polskiej kulturze prawnej pojęcie obywatela, odnoszone do mieszkańca kraju (stąd termin „krajan”), posiadającego pełnię praw i wolności obywatelskich po raz pierwszy wystąpiło

${ }^{6}$ K. Wroczyński, Obywatel, [w:] Powszechna encyklopedia filozofii, t. 7, red. A. Maryniarczyk, Lublin 2006, s. 757.

7 Zob. Arystoteles, Polityka, thum L. Piotrowicz, Warszawa 2006, ks. 3, 1275 a-b, 1276 a, 1284 a; ks. 7, rozdz. 8, 1329 a.

${ }^{8}$ Zob. J. Kamiński, hasła: Cives Romani, Civis, Civitas Romana, Civitates, [w:] Prawo rzymskie. Stownik encyklopedyczny, red. W. Wołodkiewicz, Warszawa 1986, s. 32-33.

9 Szerzej na temat osobowościowego ideału obywatela opartego na: godności (honestas), wolności (libertas), równość (aequitas) i sprawiedliwości (iustitia) zob. Arystoteles, op. cit., ks. 3, 1277 a-b. Por. M.T. Cicero, Pisma filozoficzne, t. 2, O powinnościach, tłum. W. Kornatowski, Warszawa 1960, ks. 1, 25, 85, s. 372.

10 M.T. Cicero, Pisma filozoficzne. O państwie, ks. 1, roz. 25 i 39, s. 44: „A więc państwo (res publica) jest to rzecz ludu (res populi). Lud zaś - to bynajmniej nie każde zbiorowisko ludzi skupionych dowolnym sposobem, lecz wielka ich gromada, zespolona przez uznanie tego samego prawa i przez pożytek wynikający ze wspólnego bytowania".

11 Por. hasło: Citoyen, enne, [w:] Dictionnaire alphabétique et analogique de la langue française de Paul Robert, deuxième édition entièrement revue et enrichie par Alain Rey, t. 2, Paris 1989, s. 631. 
w konstytucji majowej (Ustawa Rządowa z 3 maja 1791) ${ }^{12}$. Spojrzenie wstecz na pojęcie obywatelstwa pozwala dostrzec jego dwa aspekty: filozoficzny (ateński) związany z arystotelesowską koncepcją człowieka animal sociale jako istoty społeczno-politycznej i jurydyczny (rzymski) związany z cycerońską ideą homo iuridicus, szanującego porządek prawny i spełniającego obowiązki obywatelskie.

To tradycyjne pojmowanie obywatelstwa jako korelacji prawnej (zbiór praw i obowiązków), zachodzącej między osobą fizyczną a państwem, odnajdujemy w refleksji administracyjnoprawnej Profesora. Analizując wprowadzenie do monografii Obywatel wobec ingerencji współczesnej administracji, natrafiamy na jakże wymowną uwagę Jana Bocia:

Obywatela zaś widzę przede wszystkim jako człowieka prywatnego. Rozległość i stopień złożoności podjętego tematu wyrastają z przyczyn nieobcych świadomości badającego prawo administracyjne. Jeśli jednak nie wzmocnimy tej świadomości refleksją, iż zawsze w efekcie ostatecznym chodzi o obywatela, nauka prawa administracyjnego może powoli zejść na tory społecznej nieużyteczności ${ }^{13}$.

Jak widać, autor nie podaje expressis verbis własnej definicji „obywatela” i nigdzie tego nie czyni w swej publikacji ${ }^{14}$. Niemniej jednak zarysowany kontekst wypowiedzi każe nam ewidentnie dostrzec dwa istotne elementy kształtujące jego rozumienie wspomnianego terminu. Są nimi: prywatność oraz prymarność „obywatela”. Odnosząc się do pierwszego elementu, już na pierwszy rzut oka widać osadzenie obywatela jako człowieka prywatnego w mechanizmie oddziaływania administracji na jego sytuację prawną ${ }^{15}$. Analiza położenia prawnego obywatela wynikającego z ingerencji administracji została przeprowadzona w szerokim

12 Zob. Konstytucje Rzeczpospolitej oraz komentarz do Konstytucji RP z 1997 r., red. J. Boć, Wrocław 1998, s. 34. Etymologicznie polski wyraz obywatel wywodzi się od czeskiego rzeczownika obyvatel utworzony od czasownika obyvati — mieszkać. Zob. A. Bańkowski, Etymologiczny słownik języka polskiego, t. 2, Warszawa 2000, s. 356.

13 J. Boć, Obywatel..., s. 6.

14 W nauce prawa publicznego konstruowane są rozliczne definicje pojęcia „obywatelstwo”. Tytułem przykładu przytaczamy definicję administracyjnoprawną J. Jagielskiego, Obywatelstwo polskie. Zagadnienia podstawowe, Warszawa 1998, s. 20: „Obywatelstwo można ogólnie określić jako instytucję prawną, której istota polega na istnieniu względnie trwałego w czasie i przestrzeni węzła prawnego łączącego jednostkę z państwem i wyznaczającego jej przynależność do tego państwa, które stwarza podstawę zaistnienia kompleksu wzajemnych praw i obowiązków jednostki i państwa. Obywatelstwo należy więc traktować jako konstrukcję formalnoprawną, z której wynikają następstwa materialnoprawne w postaci szeregu określonych praw i obowiązków jednostki wobec państwa oraz państwa (jego organów) względem jednostki będącej właśnie jego obywatelem”.

15 J. Boć, Obywatel..., s. 90-112, 144-162. Autor, harmonizując doktrynalne systematyki praw i obowiązków konstytucyjnych z podmiotowym ujęciem prawa administracyjnego, wyróżnił następujące materialnoprawne sytuacje obywatela z punktu widzenia jego potrzeb: obywatel jako podmiot prawa i obowiązków osobowych, politycznych i społecznych; obywatel jako właściciel, mieszkaniec i przedsiębiorca oraz obywatel wobec reżimów specjalnych. O uniwersalności tej systematyki pochodzącej z czasów ancien régime'u świadczy jej kontynuacja w rozbudowanym treściowo fragmencie podręcznika zatytułowanym Prawo administracyjne normujące sytuacje prawne obywatela, [w:] Prawo administracyjne, red. J. Boć, Wrocław 2010, s. 444-498. Por. J. Boć, 
kontekście teoretyczno-terminologicznym przy zastosowaniu pojęć operatywnych (pojęć-narzędzi), typu: uprawnienie i obowiązek, zasięg i treść ingerencji oraz sytuacji administracyjnoprawnej. Naukotwórcze pytania: o istotę administracji i jej instrumentarium (formy, środki, metody), o kształt korelacji między administracją i obywatelem, a zwłaszcza o granice dopuszczalnej ingerencji administracji w sferę publicznych praw podmiotowych nic nie straciły na swej aktualności i doniosłości. Zważywszy na kontekst ustrojowo-polityczny ${ }^{16}$ postawienie przez Profesora w centrum badań naukowych administracyjnoprawnego statusu obywatela pozwala zakwalifikować go jako jednego ze zwolenników neoliberalnej koncepcji obywatelstwa, która miała dopiero nadejść wraz z demokratycznym państwem prawa. Neoliberałowie, akcentując rolę jednostki w społeczeństwie, z jednej strony zajmują się katalogiem praw, wolności i obowiązków człowieka, a z drugiej skupiają się na podstawowym zadaniu państwa: jak zabezpieczyć obywateli przed nadużyciami jego instytucji. Taki też tenor thésis odnajdujemy również i w tym fragmencie rozprawy, gdzie rozwijana jest problematyka zabezpieczenia procesowego sytuacji prawnych obywatela przed omnipotencją państwa działającego przez swoją administrację ${ }^{17}$.

Drugim istotnym elementem współkształtującym Bociowe rozumienie terminu „obywatel” jest jego prymarność. Atrybut ten zdaje się odsyłać — choć daje się to jedynie wyinterpretować, a nie wyczytać z tekstu — do kantowsko-personalistycznej koncepcji osoby traktowanej zawsze jako podmiot i cel, a nie jako przedmiot czy środek do celu ${ }^{18}$. Bez najmniejszego wahania można zatem

Administracja a obywatel, [w:] A. Błaś, J. Boć, J. Jeżewski, Administracja publiczna, red. J. Boć, Wrocław 2003, s. 247-257, 366-367.

16 Jak pisał: „Współcześnie bowiem wyraźniej niż kiedykolwiek adresatem norm prawa administracyjnego (zarówno ogólnych, jaki i indywidualnych) jest coraz częściej państwowa lub społeczna jednostka organizacyjna, a nie obywatel. [...] Polityczna idea prymatu państwa nad jego obywatelem wywarła niewątpliwy wpływ nie tylko na określenia administracji, ale przede wszystkim na treść systemu prawa administracyjnego i całości rozważań jego nauki. W rezultacie w polskiej literaturze prawa administracyjnego pojęcie obywatela (człowieka) jako element składowy określenia administracji, znalazło się jedynie bodaj w ujęciu F. Longchampsa”. J. Boć, Obywatel..., s. 8, 14.

17 Ibidem, s. 163-194.

18 Przypomnijmy w tym miejscu znamienne wypowiedzi reprezentantów nurtu filozofii podmiotu. I. Kant, Uzasadnienie metafizyki moralności, tłum. M. Wartenberg, Kęty 2001, s. 45: „Twierdzę oto: człowiek i w ogóle każda istota rozumna istnieje jako cel sam w sobie, nie tylko jako środek, którego ta lub owa wola mogła używać wedle swego upodobania, lecz musi być uważana zarazem za cel zawsze, we wszystkich swych czynach, odnoszących się tak do niego samego, jak też do innych istot rozumnych". J. Maritain, Principes d'une politique humaniste, Paris 1944, s. 16: „Dire que l'homme est une personne, c'est dire que dans le fond de son être il est plus un tout qu'une partie, et plus indépendant que serf. C'est dire qu'il est un minuscule fragment de matière qui est en même temps un univers - un être mendiant qui communique avec l'être absolu — une chair mortelle dont la valeur éternelle - un brin de paille dans lequel entre le ciel" [Powiedzieć, że człowiek jest osobą, to znaczy powiedzieć, że w głębi swej istoty jest całością, nie częścią. Bardziej niezależny niż poddany, maleńki fragment materii, który jest jednocześnie wszechświatem. Źdźbło 
powiedzieć, iż stąd już tylko krok do takiego pojmowania kategorii „obywatela”, w przypadku której godność osoby ludzkiej będzie miała niezaprzeczalnie pierwszoplanowe znaczenie.

\section{2.}

Przejdźmy teraz do kategorii filozoficznych zawartych w Prawniczym słowniku wyrazów trudnych i rozpocznijmy od analizy pojęcia ,autonomii”. W filozofii klasycznej autonomia w sensie etymologicznym (gr. autós — sam, nomos — prawo) to właściwość samostanowienia o sobie lub kierowania się własnymi prawami; w sensie ogólnym — niezawisłość (niezależność) jakiejś dziedziny rzeczywistości lub działania od innej, w szczególności — niezależność porządku praktycznego (wartości, obowiązków) od porządku teoretycznego (bytowego, poznawczego), człowieka od społeczeństwa lub instytucji, jednych instytucji od innych, poszczególnych dziedzin kultury od siebie lub kultury od różnych instytucji oraz niezależność świata przyrodzonego od nadprzyrodzonego ${ }^{19}$. Od starogreckiej koncepcji politei autonomia stała się wiodącym pojęciem polityki i prawoznawstwa. Analizowano rozmaite formy politycznej niezależności społeczeństw, a także stosunek autonomii do wolności ${ }^{20}$. W dobie nowożytnej zainteresowano się autonomią człowieka i stopniem jej determinacji w wyniku umowy społecznej leżącej u podstaw powstania społeczności politycznej ${ }^{21}$. Autorem koncepcji autonomii porządku praktycznego względem teoretycznego był Immanuel Kant. Uzasadniając autonomię woli, twierdził, że należy postępować według takiej normy, która mogłaby stać się powszechnym prawem ${ }^{22}$. Od XIX wieku teoretycy nauk społecznych, zwłaszcza prawoznawcy i politolodzy, opracowywali różne formy autonomii społeczności cząstkowych (federalizm, decentralizm, samorząd) czy też całościowych (suwerenność, unitaryzm, centralizm, rząd). Filozofowie prawa i kultury zaś rozważali rozmaite typy autonomii począwszy od autonomii jednostki (Heinrich Rickert), przez autonomię społeczeństwa (Max Weber), a skończywszy na autonomii norm moralnych i prawnych (Hans Kelsen).

słomy, w które wnika niebo; tłum. M. Bratuń]. Zob. A. Szadok-Bratuń, M. Bratuń, Prolegomena do wszelkiej możliwej polityki, czyli w stronę spoteczeństwa obywatelskiego, [w:] Polityka administracyjna - Administrative Policy, red. J. Łukaszewicz, Rzeszów 2008, s. 700-702.

19 S. Kamiński, Autonomia, [w:] Powszechna..., t. 1, Lublin 2000, s. 423-424; S. Kamiński i J. Herbut, Autonomia, [w:] Leksykon filozofii klasycznej, red. J. Herbut, Lublin 1997, s. 66-67.

20 Zob. przywołane wcześniej dzieła Arystotelesa, M.T. Cicerona i Platona, Państwo. Prawa (VII ksiag), tłum. W. Witwickiego, Kęty 1998.

21 Zob. J.J. Rousseau, Umowa społeczna, tłum. A. Peretiatkowicz, Kęty 2002; J. Locke, Dwa traktaty, tłum. Z. Rau, Warszawa 1992; T. Hobbes, Lewiatan, czyli materia, forma i władza państwa kościelnego i świeckiego, tłum. C. Znamierowski, Warszawa 2009.

22 I. Kant, Uzasadnienie..., s. 38. 
Zawarta $\mathrm{w}$ Prawniczym słowniku wyrazów trudnych kategoria autonomii określona została przez Jana Bocia następująco: „Autonomia — pojęcie występujące $\mathrm{w}$ wielu dziedzinach nauk $\mathrm{i} w$ języku potocznym. W prawie oznacza możliwość ustalania własnych reguł postępowania, czy możliwość funkcjonowania poza regułami dotychczas odnoszącymi się do podmiotu, który wszedł w sytuację autonomii, a w ujęciu negatywnym niezależność postępowania od innych podmiotów"23. Sformułowanie autora odnoszące się do autonomii w prawie jest precyzyjne i zarazem lapidarne. Trafnie problem stawia, lecz szczegółowo go nie rozważa, nie przybliża jego kontekstu filozoficznoprawnego. Ta redukcja semantyczna wydaje się zamierzona, skoro w kolejnym haśle „,autonomia prawa" ${ }^{24}$, następującym bezpośrednio po haśle ,autonomia”, zamieszcza on analizy o charakterze epistemologicznym, ontologicznym i aksjologicznym, ukazując tym samym szerokie tło filozoficzne prowadzonych rozważań. Czyni to jednak nie w swoim własnym imieniu, lecz za pomocą obszernego cytatu, zaczerpniętego z książki Włodzimierza Gromskiego Autonomia i instrumentalny charakter prawa ${ }^{25}$. Nieobecność odautorskiego komentarza Jana Bocia zdaje się wskazywać na pełną akceptację prezentowanych treści wrocławskiego teoretyka prawa. W taki oto sposób dzięki pogłębionej refleksji filozoficznej pojęcie autonomii prawa zawarte w Słowniku uzyskało solidną podbudowę teoretyczną i godne uwagi dopełnienie.

Filozoficznoprawne ujęcie autonomii (autonomii prawa) zaprezentowane w słownikowym haśle odnajdujemy w monografii Profesora zatytułowanej Gmi$n a w$ Belgii. Jej ostatni rozdział stanowi wykład o autonomii gminnej będącej odmianą autonomii społeczności cząstkowych, jedną z form decentralizacji ${ }^{26}$. Wykład ten skonstruowany został niejako trójstopniowo, a jego materialną podstawę stanowi poznawcza interpretacja historyczno-normatywnego statusu gminy w państwie belgijskim, bycie wielopostaciowym lingwistycznie i strukturalnie ${ }^{27}$. Na poziomie ontologicznym sformułowano podstawowy problem dotyczący istoty nie tylko autonomii gminnej, lecz szerzej — lokalnej. Doprecyzowano go katalogiem uniwersalnych pytań mających zastosowanie w analizie autonomii różnorodnych zdecentralizowanych jednostek samorządowych państw demokratycznych ${ }^{28}$.

23 Prawniczy stownik..., s. 41.

24 Ibidem, s. 41-44.

25 W. Gromski, Autonomia i instrumentalny charakter prawa, Wrocław 2000, s. 22-26.

26 J. Boć, Gmina..., s. 90-102.

27 Swoiste federalne państwo belgijskie skomponowane jest z państwa centralnego, z trzech wspólnot (niderlandzkiej, francuskiej i niemieckiej), i tyluż regionów (flamandzki, waloński i brukselski) oraz z czterech regionów językowych (francuskojęzyczny, niderlandzkojęzyczny, dwujęzyczny region brukselski i niemieckojęzyczny). Autonomiczny Region Flamandzki i Region Waloński ma strukturę dwuszczeblową, dzieli się na prowincje i gminy, a Region Brukselski jednoszczeblową, gminną. Ibidem, s. 6-23.

28 Tak brzmią Bociowe pytania: „Co jest na początku: państwo, czy jego element terytorialny. Co jest ważniejsze: efektywność centralizacji, czy sama decentralizacja niezależnie od jej efektywności. Co jest regułą: sama autonomia, czy zwierzchność nadzorcza państwa. Czy o sprawach 
Ta formuła ontologiczna uargumentowana została spojrzeniem metodologicznym i epistemologicznym.

Autonomię gminną (lokalną) w sensie metodologicznym wyeksplikowano za pomocą dwóch metod poznawczych: eksponując jej samodzielność (autonomię), a ograniczenia traktując jako kwestię drugorzędną (heteronomię), oraz akcentując obie cechy jednocześnie ${ }^{29}$. W pierwszym ujęciu zdefiniowano ją jako przysługujące gminie kompetencje do podejmowania samodzielnych decyzji w normowaniu spraw z zakresu interesu gminnego. W drugim natomiast autonomia gminna to stan względnej niezależności władzy gminnej sprawowanej pod kontrolą organów zwierzchnich w przypadkach ustawowo przewidzianych. Samodzielność gminna doznaje także ograniczenia przedmiotowego, bowiem ustawodawca nie tylko przyznaje uprawnienia gminne, ale może także je odjąć na rzecz innej władzy lokalnej czy też centralnej. Zatem gmina, nie decydując o tym, co jest jej uprawnieniem bądź interesem, staje się niejako wtórnym nosicielem kompetencji autonomii gminnej.

Na poziomie epistemologicznym autonomię gminną sprowadzono do opisu klaryfikującego rzeczywistość zadaniowo-kompetencyjną gminy belgijskiej. Wyodrębniono trzy podstawowe obszary samodzielności realizowane przez organy gminy: samorządność w zakresie reglamentowania stosunków społeczno-gospodarczych, samorządność finansową i samorządność w sferze funkcjonowania i organizacji gminy ${ }^{30}$. Jak powiada J. Boć: „Cały zakres samodzielności gmin mieści się w idei decentralizacji polegającej na odciążeniu się przez państwo z tych zadań, z którymi ono samo nie może sobie poradzić, co w jakimś stopniu odpowiada ubiegłowiecznemu zdaniu z wykładu barona Deschamps’a na Wydziale Prawa Uniwersytetu w Leuven, iż podczas gdy dobrze rządzić można $\mathrm{z}$ daleka, dobrze administrować można tylko z bliska"31.

Przeciwstawną kategorią filozoficzną autonomii zawartą w Prawniczym stowniku wyrazów trudnych jest „, heteronomia” 32 . Z filozoficznego punktu widzenia heteronomia (gr. héteros — inny, drugi; nomos — prawo, zasada) rozumiana jest jako uzależnienie jakiejś dziedziny rzeczywistości od innej. To właściwość stanowiąca przejaw niesamodzielności w bytowaniu, wartościowaniu oraz $\mathrm{w}$ postępowaniu ograniczającym wolności osób i społeczeństw (np. autokratyzm) ${ }^{33}$. W etyce kantowskiej heteronomia oznacza stan woli, która nie kieruje się imperatywem włas-

wyłącznych części ma decydować sama ta część, czy całość, której ta część jest elementem. Czy zakres i treść spraw wyłącznych części ustalane są przez samą tę część, czy przez całość. Jak określać autonomię: czy przez przydanie jej możliwości, czy poczynając od ograniczeń. Czy podmiotom autonomii dawać kompetencje, czy i określać cele". Ibidem, s. 90.

${ }^{29}$ Ibidem, s. 94-99.

30 Ibidem, s. 93-94. Por. fragmenty monografii traktujące o organizacji, funkcjonowaniu i finansowaniu gminy, s. 29-69.

31 Ibidem, s. 97.

32 Prawniczy stownik..., s. 144.

33 S. Janeczek, Heteronomia, [w:] Powszechna ..., t. 4, Lublin 2003, s. 414-415. 
nego rozumu (sumienia), czyli nie jest dla siebie prawodawcą (heteronomizm) ${ }^{34}$, lecz jest uwarunkowana poznawczo i motywacyjnie przez zewnętrzne autorytety $(\text { deontologizm })^{35}$. W etyce personalistycznej natomiast heteronomia woli ujawnia się wtedy, gdy działania człowieka determinują inne wyznaczniki niż godność osoby ludzkiej, np. normy moralności dominującej grupy społecznej lub autokratycznej jednostki. A tak pojęcie to zdefiniował J. Boć: „heteronomia to cecha niesamoistności wyrażająca się w tym, iż byt określany jest z zewnątrz" ${ }^{36}$. W przypadku kategorii „heteronomii”, podobnie jak w odniesienie do kategorii „autonomii”, mamy do czynienia z ujęciem lapidarnym, nieposiadającym dodatkowych analiz, wyjaśnień czy komentarzy. Ta syntetyczna definicja nominalna ${ }^{37}$ dzięki pojemnej denotacji pojęcia heteronomii staje się użytecznym paradygmatem dla wszelkiego typu nauk prawniczych, w tym dogmatyki prawa administracyjnego. Odczytujemy ten zabieg jako efekt zamierzony, wynikający z niewątpliwej zalety umysłu Profesora, jaką było celne, a przy tym zwięzłe ujmowanie zagadnień i problemów, zgodnie z maksymą Plauta: sapienti sat.

3.

Pochylmy się teraz nad kategoriami filozoficznymi występującymi w tekście Normatywizacja wartości w prawie administracyjnym ${ }^{38}$. Pierwszą parą pojęć filozoficznych, jakie napotykamy w rzeczonym szkicu, jest: „naturalizm etyczny”

${ }^{34}$ Heteronomizm to pogląd zdefiniowany przez I. Kanta w dwóch pracach: Krytyka praktycznego rozumu, tłum. J. Gałecki, Warszawa 1971, s. 178 i Uzasadnienie..., s. 57-58. Jego sens polega na nieuwzględnianiu w sposób właściwy autonomii woli, która winna być dla siebie prawodawcą. Zob. A. Szostek, Heteronomizm, [w:] Powszechna..., t. 4, s. 415; Prawniczy słownik..., s. 144.

35 W filozofii wyróżnia się najczęściej dwa typy deontologizmu: heteronomiczny i autonomiczny. Pierwszy odwołuje się do autorytetu istniejącego poza podmiotem czynu np. w pozytywizmie etycznym w roli instancji nakazodawczej może być państwo, naród, klasa społeczna, przywódca, partia. Drugi zaś głosi, że instancja moralnie nakazodawcza istnieje w podmiocie czynu jako imperatyw własnego rozumu, ograniczony jedynie postulatem uniwersalizacji, tzw. złotą regułą Kanta: „,nie czyń drugiemu, co tobie nie miłe”. T. Styczeń, Deontologizm, [w:] Leksykon..., s. 107-108. Por. A.L. Zachariasz, Filozofia na rozdrożu: naturalizm - antynaturalizm, [w:] Wokół naturalizacji (w) filozofii, red. B.K. Krzych, K.M. Wieczorek, Świętochłowice 2017, s. 11 n.

36 Prawniczy stownik..., s. 144.

37 Według J.W. Bremera definicja nominalna (formułowana w metajęzyku) objaśnia znaczenie danej nazwy i tym samym jest wyrażeniem drugiego stopnia w przeciwieństwie do definicji realnej (formułowanej w języku przedmiotowym), będącej wypowiedzią w języku pierwszego stopnia, która podaje istotną charakterystykę cech właściwych definiowanego przedmiotu. Definicja nominalna informuje o znaczeniu definiendum, określa jak zastępować wyrazy nieznane wyrazami już znanymi. Idem, Wprowadzenie do logiki, Kraków 2004, s. 64, 67. Podział ten w odniesieniu do nauk administracyjnych upoważnia do twierdzenia, że definicja realna urabiana jest w języku prawnym, a nominalna w prawniczym.

38 J. Boć, P. Lisowski, op. cit., s. 19-43.

Prawo 327, 2019

(C) for this edition by CNS 
i „relatywizm etyczny”39. Zgodnie z przyjętą metodologią prowadzonych rozważań rozpocznijmy ab ovo, czyli od eksplikacji etymologiczno-filozoficznej owych pojęć inkorporowanych do Bociowej refleksji jurydycznej.

Naturalizm etyczny (łac. naturalis - wrodzony, wynikający z natury; gr. ethikós - związany z moralnością) to jedna z postaci naturalizmu filozoficznego, według którego wszystkie zjawiska (kulturowe, społeczne, psychiczne, historyczne, komunikacyjne) należy tłumaczyć w odniesieniu do sfery naturalnej (przyrodzonej) bez odwoływania się do rzeczywistości ponadnaturalnej (nadprzyrodzonej). Naturalizm odrzuca poznanie świata wyłącznie za pomocą metafizyki spekulatywnej i podkreśla empiryczny charakter wiedzy oparty na fakcie, doświadczeniu i metodzie badawczej typowej dla nauk empirycznych. Stąd też naturalizm etyczny interpretuje moralność, sublimując empiryczną naturę człowieka i negując możliwość wyprowadzenia jakichkolwiek norm z antropologii postrzegającej go jako istotę duchową ${ }^{40}$. Z kolei relatywizm etyczny ${ }^{41}$ to stanowisko przypisujące sądom etycznym, ocenom wartościującym, normom moralnym oraz ich przedmiotom, takim jak: dobro, wartości i powinności charakter względny, uzależniony bądź od podmiotu wypowiadającego te sądy (relatywizm subiektywistyczny), bądź od uwarunkowań poznawczych - społecznych, kulturowych czy historycznych (relatywizm społeczny, kulturowy, historycyzm, in genere: relatywizm obiektywistyczny) ${ }^{42}$.

Oto passus, w jakim pojawiają się użyte przez Profesora przywołane pojęcia: „Wydaje się, że dostrzec można funkcjonowanie etyki w prawie i wobec prawa na mocy samego znaczenia etyki jako dziedziny mającej swój przedmiot rozważań. Wydaje się centralnym problemem normatywizacji wartości. W tym kontekście dostrzec można naturalizm etyczny i relatywizm etyczny, jako dwa nurty systemów etycznych"43. Przede wszystkim należy zauważyć, że wspomniany tekst jest fragmentem większej całości, zatytułowanej Etyczne źródła normatywizacji wartośc $i^{44}$. Jest to wprowadzenie do rozważań o skomplikowanych

39 Ibidem, s. 20.

40 Zob. S. Judycki, Zagadka naturalizmu, „Roczniki Filozoficzne” 2003, z. 3, s. 18 n. W ujęciu M.A. Krąpca naturalizm etyczny to kierunek myślowy w nurcie filozofii analitycznej krytykujący możliwość uzasadniania powinności etycznej z realnie zaistniałych faktów. Głosi on, że błędem jest uznanie prawidłowości rozumowania w stwierdzeniu obowiązku (powinności) wynikającego z jakiegoś realnie dostrzeżonego faktu, że nie występuje przechodzenie od ,,jest” do „powinien”, że w zdaniu stwierdzającym faktyczność nie kryje się powinność. Takie stanowisko reprezentował m.in. G.E. Moore, autor pojęcia błędu naturalistycznego wprowadzonego do metaetyki w Principia Ethica, London 1903, I, § 1-15. M.A. Krąpiec, Naturalizm etyczny, [w:] Powszechna ..., t. 7, Lublin 2006, s. 530.

41 Relatywizm (łac. relativus — względny; od referre — odnosić, oddawać) oznacza stanowisko głoszące, że prawda jest zmienna, stopniowalna i zależna od podmiotu poznającego bądź od okoliczności poznania. H. Kiereś, Relatywizm, [w:] Powszechna..., t. 8, Lublin 2007, s. 716.

42 T. Biesaga, Relatywizm etyczny, [w:] Powszechna..., t. 8, s. 718 n.

43 J. Boć, P. Lisowski, op. cit., s. 20.

44 Ibidem, s. 19-20. 
relacjach między administracyjnym systemem normatywnym a wartościami, innymi słowy o związkach jednego z działów prawoznawstwa z aksjologią etyczną, czyli nauką o wartościach i sądach wartościujących. Wprowadzenie mające na celu uświadomienie filozoficznoprawnych źródeł podejmowanych problemów, ze wskazaniem na funkcjonujące we współczesnej etyce nurty, poglądy i stanowiska. Otwiera ono rozważania o normatywizacji wartości w prawie administracyjnym, przyjmując niejako za punkt wyjścia aksjologiczną formułę rzymskiego jurysty Juventusa Celsusa: ius est art boni et aequi, rozpoczynającą Digesta Justyniańskie. $Z$ uwagi na charakter wprowadzający rzeczonego fragmentu mamy też tutaj do czynienia z pewnym poziomem ogólności prowadzonych rozważań, choć już w dalszych partiach tekstu przybiorą one bardziej szczegółowy kształt, wyrażający się w trzech płaszczyznach sapiencjalnych zamkniętych pytaniami: czym jest prawo administracyjne (ontologiczna), jak ono jest poznawalne (epistemologiczna) oraz jakie prawo jest dobre i słuszne (aksjologiczna).

Nie istnieje neutralne uprawianie filozofii ${ }^{45}$, zwłaszcza w odniesieniu do administracji i jej norm prawnych kreowanych dla dobra publicznego, gałęzi wiedzy uwikłanej w nurt nauk administracyjnych i społecznych. Należy zatem przywołać kolejny fragment wypowiedzi Profesora wskazujący na wybór koncepcji etycznej: naturalizmu dającego się uzgodnić z relatywizmem jako kontekstu dla prawniczych badań naukowych. Oto jego brzmienie:

Wartość, jako pojęcie, trzeba bowiem uznać za zjawisko naturalne wpisane w istotę rzeczy. Wartość ta jednak instrumentalnie relatywizuje się do określonej postaci, formy, rozstrzygnięcia zagadnienia w kontekście tego, co jest bardziej etyczne lub zgodne z wartościami normatywizacji. Trzeba tutaj oddzielić wartość etyczną i jej „normę” od normy prawnej i jej wartości. Pozytywizm prawniczy uległ wrażeniu, że konfuzja nieoddzielenia wartości etycznej od prawnej jest czymś realnym. Wydaje się, że prawo bez wartości, kształtujących się nawet indywidualnie w pewien system, trwać nie może $\mathrm{e}^{46}$.

Cytowany fragment uświadamia nam dwa poziomy koegzystencji faktu empirycznego i naukowego: poziom norm etycznych z normami prawnymi i poziom aksjologii etycznej z nauką szczegółową, administratywistyką. Naturalizm etyczny w swym paradygmacie podejmuje próbę całościowego postrzegania rzeczywi-

45 Por. A. Szadok-Bratuń, Krótkie rozważania o aksjologii, wartościach i antywartościach, [w:] Antywartości w prawie administracyjnym, red. A. Błaś, Warszawa 2016, s. 29-53. Tu na s. 2930 czytamy: „Podejmując próbę wejrzenia w tę przestrzeń koegzystencji, filozofujący administratywista najpierw musi przyswoić sobie semantykę kategorii filozoficznych, by następnie móc je transponować na obszar nauki prawa administracyjnego. Kategorie filozoficzne nie są neutralne, nie funkcjonują w próżni. Istnieją jako wytwory określonego nurtu, kierunku czy systemu filozoficznego, który różni się od innych programów filozoficznych założeniami metodologicznymi, zbiorem przyjętych aksjomatów i czynnikami kulturotwórczymi danej epoki. Wybór odpowiedniej koncepcji filozoficznej determinuje rozumienie podstawowych pojęć filozoficznych wypracowanych w jej obrębie".

46 J. Boć, P. Lisowski, op. cit., s. 20. Zob. także Z. Ziembiński, Wstęp do aksjologii dla prawników, Warszawa 1990, s. 57-70 i cyt. tam literatura. 
stości, co wymaga deskrypcji naukowej i filozoficznej. Ten kierunek myślowy nie rozdziela filozofii od nauk szczegółowych, dostrzegając ich komplementarność wobec siebie. Problematyka poznania wartości to wiodąca kwestia naturalizmu aksjologicznego. Symplifikując, można ją sprowadzić do dwóch tez: wartość jest empiryczną cechą (tak jak barwa, ciężar czy kształt) przedmiotu wartościowego, będącego wycinkiem świata doświadczalnego oraz istnieje przejście od zdań opisowych o przedmiocie i jego cechach do zdań wartościujących o nim, czyli ocen i norm ${ }^{47}$.

Jak widać, rozważania autora wiodą nas do drugiej pary pojęć filozoficznych: „wartość” i „aksjologia”, jakie napotykamy w prezentowanym tekście. Powołując się na Mieczysława Krąpca, przypomnijmy, że słowo wartość (gr. he aksía; łac. valor, praetium) rozumiemy spontanicznie, w kontekście używanego języka, jako coś, co budzi oceniające uznanie człowieka. Termin ten w różnych dziedzinach życia (gospodarka, polityka, etyka, psychologia, nauka) jest płynny aż do granic wieloznaczności; domniemywamy jednak, że z różnych powodów oznacza coś cennego, o co warto zabiegać. Obok słowa ,wartość” używane jest wyrażenie „wartość negatywna” - ze względu na podmiot oceniający takie wartości; nie są natomiast uznawane tzw. wartości neutralne ${ }^{48}$.

„Wartość” jest pojęciem częściowo synonimicznym z teorią wartości, nazywaną zamiennie aksjologią (gr. áksios — wartościowy, cenny; łac. logos — teoria, nauka). Dociekania nad wartością, czyli tym, co godne, znaczące, ważne, użyteczne, a przez to zobowiązujące (powinne) - dały początek teorii wartości czy też aksjologii ${ }^{49}$. Filozofia wartości może być pojmowana jako odrębny dział filozofii albo jako fragment metafizyki, antropologii i epistemologii, a etykę i estetykę rozumiane jako teorie wartości etycznych i estetycznych należy uważać za wyspecjalizowane części aksjologii ${ }^{50}$.

A oto co o teorii wartości w kontekście rozważań administracyjnoprawnych napisał Jan Boć:

Aksjologia jako teoria sumująca naukowo rozważania na temat wartości (ich natury, źródeł, klasyfikacji, relacji z innymi bytami itp.) stanowi jednocześnie pojęcie o najbardziej systemowym zastosowaniu, zakłada bowiem kompleksowe możliwości poznawcze w tym kontekście (co wymusza złożona natura i podobnie oceniane uwarunkowania). W tej perspektywie można więc uznać aksjologię za pojęcie na swój sposób dominujące wobec pozostałych. W tym sensie aksjologia służy do porządkowania ich poznania. Co jednak szczególnie istotne, aksjologiczny punkt widzenia dostarcza argumentów wskazujących na to, że wartości powinny stanowić byt przewyższający cele i zadania publiczne, prawa, wolności i obowiązki czy też interes publiczny ${ }^{51}$.

47 Por. A.B. Stępień, Wstęp do filozofii, Lublin 2001, s. 103.

48 M.A. Krąpiec, Wartość, [w:] Powszechna..., t. 9, Lublin 2008, s. 704.

49 H. Kiereś, Wartości teoria, [w:] Powszechna..., t. 9, s. 708.

50 A.B. Stępień, Aksjologia, [w:] Leksykon..., s. 23. Por. A. Szadok-Bratuń, Krótkie rozważania..., s. 31-36.

51 J. Boć, P. Lisowski, op. cit., s. 25-26. 
Przywołane słowa Profesora, zwłaszcza dwa ostatnie zdania, dowodnie potwierdzają postawioną przez nas we wstępie szkicu tezę. Jednakże autonomia, prymarność, uniwersalność filozofii w stosunku do innych nauk szczegółowych, w tym dogmatyki prawa administracyjnego, nie wyklucza ich wzajemnych związków. Ten typ wiedzy sapiencjalnej (gr. philosophia - umiłowanie mądrości) wspomaga krytyczną analizę faktów prawnych w oparciu o aksjologiczne podstawy, bo jak powiada autor, chodzi o badanie wartości zakotwiczonych w prawie administracyjnym. Dlatego też swoje analizy aksjonormatywne osadza w dyskursie systemowym, prowadząc go w dwuaspektowym wymiarze: epistemologicznym i ontologicznym ${ }^{52}$. A zatem Bociowa aksjologia epistemologiczna sprowadzona została z jednej strony do zobrazowania sposobów normatywizacji wartości w porządku administracyjnoprawnym ${ }^{53}$, $\mathrm{z}$ drugiej zaś do poznawczej roli języka prawnego jako instrumentu precyzacji, obiektywizacji i spójności treści regulacji prawnych ze sferą wartości. Przedmiot aksjologii ontologicznej zawężono do dylematów hierarchizowania wartości i skutków ich rzeczywistej realizacji w porządku prawnoadministracyjnym przy uwzględnieniu metodologii typowej dla administratywistyki ${ }^{54}$.

\section{Co dostrzegamy}

W subiektywnie „wypreparowanym” wycinku twórczości Jana Bocia dostrzegamy obiektywną pochwałę aksjonormatywności wywodzącą się z naturalnie otwartej postawy badawczej na etycznie wartościującą rzeczywistość prawną i prawniczą. Kwestie aksjologiczne odnoszą się do teoretycznych i praktycznych zagadnień stanowienia, wykonywania i stosowania prawa administracyjnego. Ten kontekst, podyktowany wyznaczonym przedmiotem studium, jest oczywisty i czytelny. Wybrane prace odznaczają się wysokim poziomem merytoryczności, oryginalności, uteoretycznienia oraz pogłębioną refleksją filozoficzną. Wyraźnie daje się wszak zauważyć subtelny poziom analizy, sytuujący prezentowane rozważania

52 Por. Z. Cieślak, Podstawy aksjologiczne administracji publicznej w Polsce — próba oceny, „Studia Iuridica” 2000, t. 38, s. 59-60.

53 Wskazano na stosowne źródła aksjonormatywności praktycznej m.in.: preambuły ustaw, akty normatywne o charakterze aksjologicznym czy też na przepisy prawa administracyjnego o bezpośrednich lub pośrednich konotacjach aksjologicznych. Wyartykułowano problem niedostatecznej przekładalności języka wartości na język faktów prawnych normujących ową materię. Ibidem, s. 27-38.

54 Ibidem, s. 39-41. Katalog uniwersalnych wartości w prawie administracyjnym został wskazany pośrednio (funkcjonalnie) na kanwie analizy sposobów normatywizacji wartości w porządku administracyjnoprawnym. Bezpośrednio materię tę przedstawia J. Zimmermann, Prawo administracyjne, Warszawa 2014, s. 118-127 i S. Fundowicz, Aksjologia prawa administracyjnego, [w:] Koncepcja systemu administracyjnego, red. J. Zimmermann, Warszawa 2007, s. 639-654. 
na obszarze właściwym dla naturalizmu etycznego, jednego z ważkich stanowisk we współczesnym kierunku filozoficznoprawnym. Zawarte w tekstach Profesora kategorie filozoficzne osadzone w nurcie dociekań administracyjnoprawnych ugruntowują relacje moralności z administracją publiczną, będąc wyrazem styku nomos i sophia. Związek myślenia filozoficznego z myśleniem administracyjnym wydaje się cenną wartością kultury prawniczej autora. Świadczy to bez wątpienia o głęboko uświadomionej, metodologicznie uprawomocnionej, stałej potrzebie ufilozoficznienia własnych tekstów. Wszystko to sprawia, że w efekcie finalnym istotna część dorobku naukowego wrocławskiego badacza nabiera charakteru interdyscyplinarnego, sytuując się na pograniczu prawa i filozofii.

\section{Bibliografia}

Arystoteles, Polityka, t. 3, tłum L. Piotrowicz, Warszawa 2006.

Bańkowski A., Etymologiczny słownik języka polskiego, t. 2, Warszawa 2000.

Biesaga T., Relatywizm etyczny, [w:] Powszechna encyklopedia filozofii, t. 8, red. A Maryniarczyk, Lublin 2007.

Boć J., Administracja a obywatel, [w:] A. Błaś, J. Boć, J. Jeżewski, Administracja publiczna, red. J. Boć, Wrocław 2003.

Boć J., Gmina w Belgii, Wrocław 1993.

Boć J., Obywatel wobec ingerencji wspótczesnej administracji, Wrocław 1985.

Boć J., Prawo administracyjne normujace sytuacje prawne obywatela, [w:] Prawo administracyjne, red. J. Boć, Wrocław 2010.

Boć J., Lisowski P., Normatywizacja wartości w prawie administracyjnym, [w:] Wartości w prawie administracyjnym, red. J. Zimmermann, Warszawa 2015.

Bremer J.W., Wprowadzenie do logiki, Kraków 2004.

Cicero M.T., Pisma filozoficzne, t. 2, tłum. W. Kornatowski, Warszawa 1960.

Cieślak Z., Podstawy aksjologiczne administracji publicznej w Polsce — próba oceny, „Studia Iuridica" 2000 , t. 38.

Dictionnaire alphabétique et analogique de la langue française de Paul Robert, deuxième édition entièrement revue et enrichie par Alain Rey, t. 2, Paris 1989.

Fundowicz S., Aksjologia prawa administracyjnego, [w:] Koncepcja systemu administracyjnego, red. J. Zimmermann, Warszawa 2007.

Gromski W., Autonomia i instrumentalny charakter prawa, Wrocław 2000.

Hobbes T., Lewiatan, czyli materia, forma i władza państwa kościelnego i świeckiego, tłum. C. Znamierowski, Warszawa 2009.

Jagielski J., Obywatelstwo polskie. Zagadnienia podstawowe, Warszawa 1998.

Janeczek S., Heteronomia, [w:] Powszechna encyklopedia filozofii, t. 4. red. A. Maryniarczyk, Lublin 2003.

Jeżewski J., Jan Boć (1939-2017), „Państwo i Prawo” 2017, z. 4.

Judycki S., Zagadka naturalizmu, „Roczniki Filozoficzne” 2003, z. 3.

Kamiński J., hasła: Cives Romani, Civis, Civitas romana, Civitates, [w:] Prawo rzymskie. Słownik encyklopedyczny, red. W. Wołodkiewicz, Warszawa 1986.

Kamiński S., Autonomia, [w:] Powszechna encyklopedia prawa, t. 1, red. A. Maryniarczyk, Lublin 2000. 
Kamiński S., Herbut J., Autonomia, [w:] Leksykon filozofii klasycznej, red. J. Herbut, Lublin 1997. Kant I., Krytyka praktycznego rozumu, tłum. J. Gałecki, Warszawa 1971.

Kant I., Uzasadnienie metafizyki moralności, tłum. M. Wartenberg, Kęty 2001.

Kiereś H., Relatywizm, [w:] Powszechna encyklopedii filozofii, t. 8, red. A. Maryniarczyk, Lublin 2007.

Kiereś H., Wartości teoria, [w:] Powszechna encyklopedia filozofii, t. 9, red. A. Maryniarczyk, Lublin 2008.

Konstytucje Rzeczpospolitej oraz komentarz do Konstytucji RP z 1997 r., red. J. Boć, Wrocław 1998.

Krąpiec M.A., Naturalizm etyczny, [w:] Powszechna encyklopedia filozofii, t. 7, red. A. Maryniarczyk, Lublin 2006.

Krąpiec M.A., Wartość, [w:] Powszechna encyklopedia filozofii, t. 9, red. A. Maryniarczyk, Lublin 2008.

Locke J., Dwa traktaty, tłum. Z. Rau, Warszawa 1992.

Maritain J., Principes d'une politique humaniste, Paris 1944.

Między tradycją a przyszłościa w nauce prawa administracyjnego. Księga jubileuszowa dedykowana Profesorowi Janowi Bociowi, red. J. Supernat, Wrocław 2009.

Moore G.E., Principia Ethica, London 1903.

Platon, Państwo. Prawa (VII ksiag), tłum. W. Witwicki, Kęty 1998.

Prawniczy słownik wyrazów trudnych, red. J. Boć, Wrocław 2005.

Profesora Jana Bocia styl - słowa - szkoła, red. A. Szadok-Bratuń, Wrocław 2009.

Rousseau J.J., Umowa społeczna, tłum. A. Peretiatkowicz, Kęty 2002.

Stępień A.B., Aksjologia, [w:] Leksykon filozofii klasycznej, red. J. Herbut, Lublin 1997.

Stępień A.B., Wstęp do filozofii, Lublin 2001.

Styczeń T., Deontologizm, [w:] Leksykon filozofii klasycznej, red. J. Herbut, Lublin 1997.

Szadok-Bratuń A., Krótkie rozważania o aksjologii, wartościach i antywartościach, [w:] Antywartości w prawie administracyjnym, red. A. Błaś, Warszawa 2016.

Szadok-Bratuń A., W nauce nie ma pożegnań - pamięci Profesora Jana Bocia, „Studia Prawa Publicznego" 2017, nr 1.

Szadok-Bratuń A., Bratuń M., Prolegomena do wszelkiej możliwej polityki, czyli w stronę społeczeństwa obywatelskiego, [w:] Polityka administracyjna - Administrative Policy, red. J. Łukaszewicz, Rzeszów 2008.

Szostek A., Heteronomizm, [w:] Powszechna encyklopedia filozofii, t. 4, red. A. Maryniarczyk, Lublin 2003.

Wroczyński K., Obywatel, [w:] Powszechna encyklopedia filozofii, t. 7, red. A. Maryniarczyk, Lublin 2006.

Zachariasz A.L., Filozofia na rozdrożu: naturalizm — antynaturalizm, [w:] Wokół naturalizacji (w) filozofii, red. B.K. Krzych, K.M. Wieczorek, Świętochłowice 2017.

Ziembiński Z., Wstęp do aksjologii dla prawników, Warszawa 1990.

Zimmermann J., Prawo administracyjne, Warszawa 2014. 


\title{
On certain philosophical categories in the administrative and legal output of professor Jan Boć
}

\author{
Summary
}

The authors of this article analyze selected philosophical categories contained in administrative and legal publications by professor Jan Boć. In this way they want to focus the reader's attention on the presence of philosophical reflection in the works of a representative of the Wrockaw school of cameralistics. The basis for the considerations are the following texts by the professor: monographs entitled Obywatel wobec ingerencji współczesnej administracji (Citizen against the interference of modern administration) and Gmina w Belgii (Commune in Belgium), the author's entries contained in the legal dictionary of difficult words, as well as the article entitled "Normatywizacja wartości w prawie administracyjnym" (Normativization of values in administrative law) (co-authored with Piotr Lisowski).

The article begins with a reminder of basic facts from the biography of professor Jan Boć. Then, the concept of a "citizen" is examined, analyzed in the historiosophical and administrative-legal contexts. The following categories of philosophy, considered in the comparative aspect, are discussed: "autonomy", "heteronomy", "ethical naturalism", "ethical relativism", "value" and "axiology".

In the conclusion of their investigations, the authors emphasize the objective praise of the axiormormality of professor Jan Boć that appears in his studies, as well as of the very high level of their substantiveness, originality and constant, deepened philosophical reflection. In a special way they highlight the fact that the relationship between philosophical thinking and administrative law was a valuable asset of the legal culture of Jan Boć.

Keywords: administrative law, axiology, value, autonomy, heteronomy, ethical relativism, ethical naturalism, citizen, Jan Boć. 